\title{
EFFECT OF BIO FERTILIZER, ORGANIC MANURE SOURCES AND APPLICATION METHOD ON GROWTH, LEAF MINERAL CONTENT, YIELD AND FRUIT QUALITY OF FLAMESEEDLEES GRAPES
}

\author{
A. E. Hassan and M. A. M. Salem \\ Hort. Dept., Faculty of Agriculture, Menoufia University; Shebin El.Kom \\ Received: Oct. 27,2020 \\ Accepted: Nov. 4,2020
}

\begin{abstract}
This investigation was conducted for two successive seasons (20162017) in a private vineyard located at El-Sadat, Menoufia governorate; on Flame seedless grapevines to study the effect of organic fertilizers, application method and bio fertilizers for Flame seedless grapevines by using different sources of organic fertilizers. The chosen vines were seven years old, grown in a sandy loam soil, spaced at $2 \times 3$ meters apart, irrigated by the drip system, and spur-pruned and trellised by $Y$ Shape system. Organic fertilizers (compost, city west compost and chicken manure) were applied either in the form of individual by (trench or superficial) application method. Bio fertilizers (Nitrobien and Rhizobacterien) were applied either in the form of individual as a twelve treatments. This study indicated that application of poultry manure with trench application + Rhizobacterien was the best management system for achieving the best vegetative growth parameters, leaf mineral content and ensuring the best yield with fruit quality at tributes of Flame Seedless grapevines.
\end{abstract}

Key words: Grape, Flame seedless, organic fertilizer, Compost, Rhizobacterien, Biofertilizer, Nitrobien and Organic manure application method.

\section{INTRODUCTION}

On worldwide basis, grapes (Vitis vinefera,L.) considered the fourth crop while it ranked the first largest deciduous fruit crop. In Egypt, grape occupies the second rank after citrus. The total grape area in Egypt reached 197894 feddans with production of 1695341 Tons according to the latest statistics of Ministry of Agriculture (2016).

Fertilization is one of the most important cultural practices carried out during the growing season, especially organic fertilization. Organic fertilization is another option for supplying macro and micro nutrients necessary for plant growth (Harhash and Abdel-Nasser, 2000). In addition, the organic materials improve soil structure, aeration, and retention of moisture and reduce soil $\mathrm{pH}$ (EL-Nagar, 1996 and Nassar, 1998). The possibility of using the organic fertilization for increasing growth and improving nutritional status of grapevines was approached by many researchers (Zhu and Zhu, 2000; Guo et al., 2000; Kassem and Marzouk, 2002; Hussein et al., 2005 and Omar, 2005).

On the other hand, the application method or organic manure materially affects the utilization and efficiency of organic manure. In this respect, Abd ElWahab (2011) on Red Globe grapevines mentioned that the application of organic manure in trenches increased the utilization and efficiency of organic manure which reflected in better growth, higher leaf mineral content, higher tree yield and better quality rather than superficial application.

Biofertilizers, more appropriately microbial inoculants, are the preparations containing one or more species of microorganisms which have the ability to capture or mobilize nutritionally important plant nutrients 
from non-usable to usable form through the biological processes such as $\mathrm{N}$ fixation, $P$ solubilization, excretion of plant growth enhancers, or cellulose degradation in soil, compost, and other environments (Vessey 2003; Trimurtulu and Rao 2014 and Pal et al., 2015). Biofertilizers are low-cost and environment-friendly supplement to chemical fertilizers and manures. Recently, biofertilizers are gaining momentum due to its ability to maintain soil health, minimize environmental degradation, and cut down the use of inorganic fertilizers in agriculture. These inputs gained added importance in rainfed agriculture in view of their low cost, as small to marginal farmers across the globe cannot afford expensive chemical fertilizers (Barman et al., 2017). Biofertilizers could be an ideal input for cutting the cost of production and for practicing organic and conservation farming (Singh et al., 2016). These organisms can be engaged in maintaining long-term soil fertility and sustainability (Sharma et al., 2015 and Shelat et al., 2017).

Thereupon, the main target of this study is to throw some light on the organic cultivation through the evaluation of the effect of different organic manure sources namely compost, poultry, waste of cities and manure application method i.e. superficial and trench application, besides two biofertilizers ( $N$ - fixing bacteria) namely Nitrobin and Rhizobacterien as well as their combination on vegetative growth, leaf mineral content, yield and its components as well as fruit quality attributes of Flame seedless grapevines.

\section{MATERIALS AND METHODS}

This investigation was carried out during two consecutive seasons of 2016 and 2017 in a private vineyard located at
El-Sadat City, Menoufia Governorate on Flame seedless grapevines to study the effect of different organic manure sources namely compost, poultry, waste cities compost and manure application method i.e. superficial and trench application, besides two biofertilizers (Nfixing bacteria) namely Nitrobin and Rhizobacterien as well as their interaction on vegetative growth, leaf mineral content, yield and its components as well as fruit quality attributes. The chosen vines were seven years old grown in sandy soil, spaced at $2 \times 3$ meters apart, irrigated by the drip system, spur-pruned and trellised by $Y$ Shape system.

The vines were pruned during the third week of December in both seasons of the study so as to maintain a load of 72 eyes/vine (16 fruiting spurs $X$ four eyes plus four renewal spurs $X$ two eyes).

Seventy two Flame grapevines, healthy, nearly uniform in growth vigor and received regularly the recommended horticultural practices were selected for this study. However, three factors were evaluated during the present study as follows:

\section{(1) Organic manure source}

Three sources of organic manure were evaluated i.e., Compost (plant and animal residues), poultry and City west compost. Chemical analyses of the tested organic manure sources are presented in Table (1). According to the recommended dose of Ministry of Agriculture, the actual amount of nitrogen ( $g / v i n e / y e a r)$ required to 7- year - old to Flame grapevines grown in sandy soil is $60 \mathrm{~g} / \mathrm{N} / \mathrm{vine} / \mathrm{year}$.

Consequently half of the required amount of nitrogen (30 g/vine/year) was suggested to be satisfied through one of the tested organic manure sources compost, poultry and city west compost as follows: 
Table (1): Chemical analysis of the tested organic manure sources (City west compost, Poultry manure And Compost)

\begin{tabular}{|l|l|l|l|l|l|c|c|c|c|c|}
\hline $\begin{array}{l}\text { Organic } \\
\text { manure } \\
\text { source }\end{array}$ & $\mathrm{N} \%$ & $\mathrm{P} \%$ & $\mathrm{~K} \%$ & $\mathrm{Ca} \%$ & $\mathrm{Mg} \%$ & $\begin{array}{c}\mathrm{Fe} \\
(\mathrm{ppm})\end{array}$ & $\begin{array}{c}\mathrm{Mn} \\
(\mathrm{ppm})\end{array}$ & $\begin{array}{c}\mathrm{Zn} \\
(\mathrm{ppm})\end{array}$ & $\begin{array}{c}\text { Organic } \\
\text { carb\% }\end{array}$ & $\mathrm{C} / \mathrm{N} \%$ \\
\hline $\begin{array}{l}\text { City west } \\
\text { compost }\end{array}$ & 2.24 & 0.12 & 0.57 & 0.63 & 0.95 & 1532 & 475 & 512 & 25.0 & 11.16 \\
\hline Poultry & 2.38 & 0.64 & 0,76 & 1.94 & 0.73 & 3245 & 519 & 632 & 42.56 & 17.89 \\
\hline Compost & 1.25 & 0.57 & 0.62 & 0.48 & 0.54 & 2876 & 975 & 328 & 18.29 & 14.63 \\
\hline
\end{tabular}

a. City west compost manure $(2.24 \% \mathrm{~N})$ about $13.4 \mathrm{Kg} / \mathrm{vine} /$ year with $\mathrm{C} / \mathrm{N}$ ratio 11.16:1

b. Poultry manure $(2.38 \% \mathrm{~N})$ about 12.6 $\mathrm{Kg} / \mathrm{vine} /$ year with $\mathrm{C} / \mathrm{N}$ ratio 17.89:1

c. Compost $(1.25 \% \mathrm{~N})$ about $24 \mathrm{Kg} / \mathrm{vine}$ /year with $\mathrm{C} / \mathrm{N}$ ratio 14.63:1

\section{(2) Organic manure application method}

Two organic manure application methods of the three tested organic manure sources namely (City west compost, Poultry manure and Compost) were evaluated as follows:

a. Superficial application: Well decomposed organic manure of the three evaluated sources were applied superficially and digged in the soil during deep hand hoeing practice (about $20 \mathrm{~cm}$ depth) in mid December of each season.

b. Trench application: In late December of each season, two trenches $(80 \mathrm{~cm}$ length $\times 25 \mathrm{~cm}$ width $\times 20 \mathrm{~cm}$ depth) were digged along both sides of the vine at one meter apart from vine trunk in the directions of irrigation furrows. Thereafter, the calculated amount of each organic manure source (city west compost, Poultry manure And Compost) was equally divided into two halves and applied in the two trenches (half amount of each organic manure source / tranche) and covered with tranche soil.

\section{(3) Biofertilization ( $\mathrm{N}$ - fixing bacteria)}

The remained amount of the required nitrogen for each vine of each year $(30 \mathrm{~g} / \mathrm{N} / \mathrm{vine} /$ year) was assumed to be partially satisfied through using the materials of $\mathrm{N}$-fixing bacteria. In the first week of March of each season, flame seedless vines were inoculated with Nitrobien (100g/vine) or Rhizobactrien (150 g/vine). The tested biofertilizers were applied in trenches $(40 \mathrm{~cm}$ length $\times 20 \mathrm{~cm}$ width $\times 20 \mathrm{~cm}$ depth), Irrigation was conducted after biofertilizers application.

Therefore, this study included three factors (three organic manure $x$ two organic manure application methods $x$ two biofertilizers

The treatments were arranged in a split plot design and each treatment was replicated three times and each replicate was represented by two vines .

The following parameters were adopted to evaluate the tested treatments:

\section{Vegetative growth characteristics:}

a) Average main shoot length $(\mathrm{cm})$.

b) Number of leaves /shoot

c) Average leaf area (cm2) as a result of measuring the maximum diameter of 
twenty mature leaves from those leaves opposite to the basal clusters on main shoot/ vine and the leaf area was estimated according to the following equation reported by (Ahmed and Morsy 1999).

Leaf area $(\mathrm{cm} 2)=0.45(0.79 \times$ w2 $)+17.77$

\section{Leaf mineral content:}

Representative petioles sample was taken and analyzed for macro nutrients after washing in sequence with tap water, $0.01 \mathrm{NHCl}$ acidified bid stilled water and bid stilled water, respectively and then dried in a ventilated oven at $700 \mathrm{oc}$ for 72 $h$. till constant weight. The plant samples were ground in stainless steel mill of $\mathbf{0 . 0 5}$ $\mathrm{mm}$ sieve and kept in plastic containers. and total nitrogen, phosphorus and potassium in leaf petioles was calculated as percentage

a) Determination of total nitrogen: Total nitrogen was determined calorimetrically by Nessler method as reported by Chapman and Pratt (1965) by using Micro Kjeldahal.

b) Determination of total phosphorus: Phosphorus in the leaf petioles was determined by using Olsen method as reported by Wilde et al, (1985) by using spectrophotometer.

c) Determination of total potassium: Potassium in the leaf petioles was determined by using flame photometer as outlined by (Chapman and Pratt (1965) by using Flame Photometer.

\section{Yield and its components:}

Harvesting took place when T.S.S./acid in the berries of the check treatment reached at least 25:1 (at the last week of June in both seasons) (according to Weaver, 1976).Yield per vine expressed in weight (Kg.) was determined as number of clusters/vine $X$ average cluster weight (g).

\section{Berries quality:}

Five clusters from each vine were taken at random for determination of the following physical and chemical characteristics.

a) Average weight of 100 berry (g.)

b) Average size of 100 berry (cm3)

c) Percentage of total soluble solids in the juice by using hand refract meter.

d) Percentage of total acidity (as $\mathrm{g}$ tartaric acid / $100 \mathrm{ml}$ juice) by titration $\begin{array}{llll}\text { against } & 0.1 & \mathrm{NaOH} & \text { using }\end{array}$ phenolphthalein as an indicator A.O.A.C (2000).

e) T.S.S./ acid was calculated by dividing T.S.S by total acidity

\section{Experimental design and statistical Analysis}

The split plot design was adopted for this experiment. The statistical analysis of the present data was carried out and Averages were compared New L.S.D. values at $5 \%$ level (Snedecor and Cochran 1990).

\section{RESULTS AND DISCUSSION}

\section{Vegetative growth}

Date in Tables $(2,3$ \& 4) show effect of different organic manure sources with application method and bio-fertilizers ( $\mathrm{N}$ fixing bacteria) on vegetative growth characteristics i.e. average shoot length, average number of leaves and average leaf area of Flame Seedless grapevines during 2016 and 2017 seasons.

\section{a. Shoot length}

Regarding different organic manure sources with application method treatments, data clarify that all organic manure sources with trench application had the highest significant values as compared to with superficial application. Highest significant shoot length was obtained with poultry manure followed by compost, while city west compost came in the third position in both seasons of study. 
Effect of bio fertilizer, organic manure sources and application method on

Table (2): Effect of organic fertilizer with application method and bio-fertilizer application on average shoot length $(\mathrm{cm})$ of Flame Seedless grapevines during 2016 and 2017 seasons

\begin{tabular}{|l|c|c|c|c|c|c|}
\hline \multirow{2}{*}{ Brganic fertilizer } & \multicolumn{2}{|c|}{ Biortilizer } & Rhizobacterien & \multicolumn{2}{|c|}{ Nitrobien } & \multicolumn{2}{|c|}{ Mean } \\
\cline { 2 - 8 } & 1 st & 2nd & 1 st & 2nd & 1st & 2nd \\
\hline Poultry manure with trench application & 185.52 & 199.62 & 168.33 & 186.26 & 176.93 & 192.94 \\
\hline $\begin{array}{l}\text { Poultry manure with superficial } \\
\text { application }\end{array}$ & 166.65 & 181.48 & 163.25 & 180.42 & 164.95 & 180.95 \\
\hline Compost with trench application & 168.29 & 183.34 & 167.28 & 183.03 & 167.79 & 183.18 \\
\hline Compost with superficial application & 162.17 & 178.31 & 160.86 & 175.85 & 161.51 & 177.08 \\
\hline City west compost with trench application & 155.77 & 171.58 & 154.64 & 169.89 & 155.20 & 170.73 \\
\hline $\begin{array}{l}\text { City west compost with superficial } \\
\text { application }\end{array}$ & 152.79 & 169.37 & 143.46 & 159.97 & 148.13 & 164.67 \\
\hline Mean & 165.20 & 180.62 & 159.64 & 175.90 & & \\
\hline
\end{tabular}

New L.S.D at $5 \%$

Organic fertilizer

Bio-fertilizer Interaction

First season

6.61

4.69

9.38

Second season

6.25

4.43

8.86

Table (3): Effect of organic fertilizer with application method and bio-fertilizer application on average number of leaves of Flame Seedless grapevines during 2016 and 2017 season

\begin{tabular}{|l|c|c|c|c|c|c|}
\hline \multirow{2}{*}{ Brganic fertilizer } & \multicolumn{2}{|c|}{ Rhizobacterien } & \multicolumn{2}{c|}{ Nitrobien } & \multicolumn{2}{c|}{ Mean } \\
\cline { 2 - 7 } & 1 st & 2nd & 1 st & 2nd & 1st & 2nd \\
\hline Poultry manure with trench application & 32.74 & 35.22 & 29.93 & 32.87 & 31.34 & 34.05 \\
\hline Poultry manure with superficial application & 29.64 & 32.27 & 28.89 & 32.08 & 29.26 & 32.18 \\
\hline Compost with trench application & 29.75 & 32.35 & 29.67 & 32.19 & 29.71 & 32.27 \\
\hline Compost with superficial application & 28.62 & 31.63 & 28.43 & 31.27 & 28.52 & 31.45 \\
\hline City west compost with trench application & 27.68 & 30.51 & 27.29 & 29.98 & 27.48 & 30.24 \\
\hline $\begin{array}{l}\text { City west compost with superficial } \\
\text { application }\end{array}$ & 26.96 & 29.89 & 25.51 & 28.45 & 26.24 & 29.17 \\
\hline Mean & 29.23 & 31.98 & 28.29 & 31.14 & & \\
\hline
\end{tabular}

New L.S.D at $5 \%$

Organic fertilizer

Biofertilizer

Interaction

First season

1.14

0.81

1.62

Second season

1.04

0.74

1.48 
Table (4): Effect of organic fertilizer with application method and bio-fertilizer application on average leaf area (cm2) of Flame Seedless grapevines during 2016 and 2017 seasons

\begin{tabular}{|c|c|c|c|c|c|c|}
\hline \multirow[b]{2}{*}{ Organic fertilizer } & \multicolumn{2}{|c|}{ Rhizobacterien } & \multicolumn{2}{|c|}{ Nitrobien } & \multicolumn{2}{|l|}{ Mean } \\
\hline & 1st & 2nd & 1st & 2nd & 1st & 2nd \\
\hline Poultry manure with trench application & 153.77 & 165.45 & 139.52 & 154.38 & 146.65 & 159.92 \\
\hline Poultry manure with superficial application & 138.13 & 150.42 & 135.31 & 149.54 & 136.72 & 149.98 \\
\hline Compost with trench application & 139.49 & 151.96 & 138.65 & 151.70 & 139.07 & 151.83 \\
\hline Compost with superficial application & 134.41 & 147.79 & 133.33 & 145.75 & 133.87 & 146.77 \\
\hline City west compost with trench application & 129.11 & 142.21 & 128.17 & 140.81 & 128.64 & 141.51 \\
\hline City west compost with superficial application & 126.64 & 140.38 & 118.91 & 132.59 & 122.78 & 136.49 \\
\hline Mean & 136.93 & 149.70 & 132.32 & 145.80 & & \\
\hline New L.S.D at $5 \%$ & \multicolumn{3}{|c|}{ Organic fertilizer } & \multicolumn{2}{|c|}{ Bio-fertilizer } & nteraction \\
\hline First season & \multicolumn{3}{|l|}{5.46} & \multicolumn{2}{|l|}{3.87} & 7.74 \\
\hline Second season & \multicolumn{2}{|l|}{4.99} & & 3.54 & & 7.08 \\
\hline
\end{tabular}

With respect to bio-fertilizers application, data show that vines receiving of Rhizobacterien application produced significantly the highest values as compared to Nitrobien application, which it had significantly the least one in both seasons of study.

Concerning interaction between type of organic manure with application method and bio-fertilizers application, the highest significant values was attained by poultry manure with trench application + Rhizobacterien, whereas city west compost with superficial application + Nitrobien resulted in significantly the least one in both seasons of study.

\section{b. Number of leaves}

Regarding different organic manure sources with application method treatments, data clarify that all organic manure sources with trench application had the highest significant values as compared to with superficial application. Highest significant number of leaves was obtained with poultry manure followed by compost, while city west compost came in the third position in both seasons of study.

With respect to bio-fertilizers application, data show that vines receiving of Rhizobacterien application produced significantly the highest values as compared to Nitrobien application, which it had significantly the least one in both seasons of study.

Concerning interaction between type of organic manure with application method and bio-fertilizers application, the highest significant values was attained by poultry manure with trench application + Rhizobacterien, whereas city west compost with superficial application + Nitrobien resulted in significantly the least one in both seasons of study.

\section{c. Leaf area}

Regarding different organic manure sources with application method treatments, data clarify that all organic manure sources with trench application had the highest significant values as 
compared to with superficial application. Highest significant leaf area was obtained with poultry manure followed by compost, while city west compost came in the third position in both seasons of study.

With respect to bio-fertilizers application, data show that vines receiving of Rhizobacterien application produced significantly the highest values as compared to Nitrobien application, which it had significantly the least one in both seasons of study.

Concerning interaction between type of organic manure with application method and bio-fertilizers application, the highest significant values was attained by poultry manure with trench application + Rhizobacterien, whereas city west compost with superficial application + Nitrobien resulted in significantly the least one in both seasons of study.

These results are in harmony with those obtained by Abdel-Raheem et al., (2015) who found that supplying Superior grapevines with $\mathrm{N}$ as $75 \%$ chicken manure plus $9 \mathrm{ml}$ nitrobein/vine/year resulted in an obvious promoting on shoot length, number of leaves / shoot, leaf area and pruning wood weight comparing with using $N$ as $100 \%$ inorganic and Salama (2002) showed that Balady mandarin manured in trench method produced greater shoots of each flush, greater number of leaves per shoot of each flush and larger leaf surface area than those manured superficially

As for the effect of bio-fertilizers application, Ahmed (2007) found that using the suitable $N$ through $40 \%$ inorganic $+50 \mathrm{~g}$ Micrpbien, Biogen or Nitrobien was essential for stimulating the leaf area and the min shoot length of grapevine cvs Thompson, Flame and Ruby. Application of Nitrobien, Micrpbien and Biogen in descending order was effective in this respect.

\section{Leaf mineral content}

As shown in (Tables $5,6 \& 7$ ), it is obvious that leaf content of percentages of total nitrogen, phosphorus and potassium were significantly affected by organic manure with application method and bio-fertilizers application treatments during 2016 and 2017 seasons.

\section{a. Nitrogen}

Regarding different organic manure sources with application method treatments, data clarify that all organic manure sources with trench application had the highest significant values as compared to with superficial application. Highest significant leaf nitrogen content was obtained with poultry manure followed by compost, while city west compost came in the third position in both seasons of study.

With respect to bio-fertilizers application, data show that vines receiving of Rhizobacterien application produced significantly the highest values as compared to Nitrobien application, which it had significantly the least one in both seasons of study.

Concerning interaction between type of organic manure with application method and bio-fertilizers application, the highest significant values was attained by poultry manure with trench application + Rhizobacterien, whereas city west compost with superficial application + Nitrobien resulted in significantly the least one in both seasons of study. 
Table (5): Effect of organic fertilizer with application method and bio-fertilizer application on leaf nitrogen content (\%) of Flame Seedless grapevines during 2016 and 2017 seasons

\begin{tabular}{|c|c|c|c|c|c|c|}
\hline \multirow{2}{*}{ Organic fertilizer Bio-fertilizer } & \multicolumn{2}{|c|}{ Rhizobacterien } & \multicolumn{2}{|c|}{ Nitrobien } & \multicolumn{2}{|c|}{ Mean } \\
\hline & 1st & 2nd & 1st & 2nd & 1st & 2nd \\
\hline Poultry manure with trench application & 1.64 & 1.76 & 1.53 & 1.69 & 1.59 & 1.73 \\
\hline $\begin{array}{l}\text { Poultry manure with superficial } \\
\text { application }\end{array}$ & 1.52 & 1.63 & 1.52 & 1.63 & 1.52 & 1.63 \\
\hline Compost with trench application & 1.53 & 1.64 & 1.52 & 1.64 & 1.53 & 1.64 \\
\hline Compost with superficial application & 1.51 & 1.63 & 1.51 & 1.62 & 1.51 & 1.63 \\
\hline $\begin{array}{l}\text { City west compost with trench } \\
\text { application }\end{array}$ & 1.51 & 1.62 & 1.50 & 1.59 & 1.51 & 1.61 \\
\hline $\begin{array}{l}\text { City west compost with superficial } \\
\text { application }\end{array}$ & 1.50 & 1.59 & 1.49 & 1.53 & 1.50 & 1.56 \\
\hline Mean & 1.54 & 1.65 & 1.51 & 1.62 & & \\
\hline New L.S.D at $5 \%$ & Orga & ertilizer & Bio & tilizer & & ction \\
\hline First season & 0.01 & & 0.01 & & 0.02 & \\
\hline Second season & 0.03 & & 0.02 & & 0.04 & \\
\hline
\end{tabular}

Table (6): Effect of organic fertilizer with application method and bio-fertilizer application on leaf phosphorus content (\%) of Flame Seedless grapevines during 2016 and 2017 seasons

\begin{tabular}{|c|c|c|c|c|c|c|c|}
\hline \multirow{2}{*}{ Organic fertilizer } & \multirow{2}{*}{ Bio-fertilizer } & \multicolumn{2}{|c|}{ Rhizobacterien } & \multicolumn{2}{|c|}{ Nitrobien } & \multicolumn{2}{|c|}{ Mean } \\
\hline & & 1st & 2nd & 1 st & 2nd & 1st & 2nd \\
\hline \multicolumn{2}{|c|}{ Poultry manure with trench application } & 0.35 & 0.37 & 0.35 & 0.36 & 0.35 & 0.37 \\
\hline \multicolumn{2}{|c|}{ Poultry manure with superficial application } & 0.33 & 0.34 & 0.32 & 0.34 & 0.33 & 0.34 \\
\hline \multicolumn{2}{|l|}{ Compost with trench application } & 0.34 & 0.35 & 0.33 & 0.34 & 0.34 & 0.35 \\
\hline \multicolumn{2}{|l|}{ Compost with superficial application } & 0.32 & 0.33 & 0.31 & 0.33 & 0.32 & 0.33 \\
\hline \multicolumn{2}{|c|}{ City west compost with trench application } & 0.31 & 0.33 & 0.31 & 0.32 & 0.31 & 0.33 \\
\hline \multicolumn{2}{|c|}{ City west compost with superficial application } & 0.31 & 0.32 & 0.29 & 0.31 & 0.30 & 0.32 \\
\hline \multicolumn{2}{|l|}{ Mean } & 0.33 & 0.34 & 0.32 & 0.33 & & \\
\hline New L.S.D at $5 \%$ & \multicolumn{3}{|c|}{ Organic fertilizer } & -fer & & \multicolumn{2}{|c|}{ Interaction } \\
\hline First season & \multicolumn{2}{|l|}{0.01} & \multicolumn{3}{|c|}{0.01} & \multicolumn{2}{|l|}{0.02} \\
\hline Second season & \multicolumn{2}{|l|}{0.01} & \multicolumn{3}{|c|}{0.01} & 0.02 & \\
\hline
\end{tabular}


Table (7): Effect of organic fertilizer with application method and bio-fertilizer application on leaf potassium content (\%) of Flame Seedless grapevines during 2016 and 2017 seasons

\begin{tabular}{|c|c|c|c|c|c|c|}
\hline \multirow[b]{2}{*}{ Organic fertilizer } & \multicolumn{2}{|c|}{ Rhizobacterien } & \multicolumn{2}{|c|}{ Nitrobien } & \multicolumn{2}{|c|}{ Mean } \\
\hline & 1st & 2nd & $1 \mathrm{st}$ & 2nd & 1st & 2nd \\
\hline Poultry manure with trench application & 1.63 & 1.70 & 1.55 & 1.61 & 1.59 & 1.66 \\
\hline Poultry manure with superficial application & 1.52 & 1.55 & 1.52 & 1.54 & 1.52 & 1.55 \\
\hline Compost with trench application & 1.53 & 1.56 & 1.52 & 1.56 & 1.53 & 1.56 \\
\hline Compost with superficial application & 1.52 & 1.54 & 1.51 & 1.53 & 1.52 & 1.54 \\
\hline City west compost with trench application & 1.51 & 1.53 & 1.50 & 1.52 & 1.51 & 1.53 \\
\hline City west compost with superficial application & 1.49 & 1.51 & 1.45 & 1.49 & 1.47 & 1.50 \\
\hline Mean & 1.53 & 1.57 & 1.51 & 1.54 & & \\
\hline New L.S.D at $5 \%$ & \multicolumn{2}{|c|}{ Organic fertilizer } & \multicolumn{2}{|c|}{ Bio-fertiliz } & \multicolumn{2}{|c|}{ er Interaction } \\
\hline First season & \multicolumn{2}{|c|}{0.03} & \multicolumn{2}{|c|}{0.02} & \multicolumn{2}{|c|}{0.04} \\
\hline Second season & \multicolumn{2}{|c|}{0.01} & \multicolumn{2}{|c|}{0.01} & \multicolumn{2}{|c|}{0.02} \\
\hline
\end{tabular}

\section{b. Phosphorus}

Regarding different organic manure sources with application method treatments, data clarify that all organic manure sources with trench application had the highest significant values as compared to with superficial application. Highest significant leaf phosphorus content was obtained with poultry manure followed by compost, while city west compost came in the third position in both seasons of study.

With respect to bio-fertilizers application, data show that vines receiving of Rhizobacterien application produced significantly the highest values as compared to Nitrobien application, which it had significantly the least one in both seasons of study.

Concerning interaction between type of organic manure with application method and bio-fertilizers application, the highest significant values was attained by poultry manure with trench application + Rhizobacterien, whereas city west compost with superficial application + Nitrobien resulted in significantly the least one in both seasons of study.

\section{c. Potassium}

Regarding different organic manure sources with application method treatments, data clarify that all organic manure sources with trench application had the highest significant values as compared to with superficial application. Highest significant leaf potassium content was obtained with poultry manure followed by compost, while city west compost came in the third position in both seasons of study.

With respect to bio-fertilizers application, data show that vines receiving of Rhizobacterien application produced significantly the highest values as compared to Nitrobien application, which it had significantly the least one in both seasons of study.

Concerning interaction between type of organic manure with application method and bio-fertilizers application, the 
highest significant values was attained by poultry manure with trench application + Rhizobacterien, whereas city west compost with superficial application + Nitrobien resulted in significantly the least one in both seasons of study.

The obtained results are in agreement with those given by (Abdel -Reheem et al, 2015) stated that) percentages of N,P and $\mathrm{K}, \mathrm{Mg}, \mathrm{Ca}, \mathrm{Zn}, \mathrm{Fe}$ and $\mathrm{Mn}$ in the leaves of Superior grapevines were remarkably enhanced in response to supplying the vines with $\mathrm{N}$ as $75 \%$ poultry manure and Salama (2002) compared three organic manure sources namely cattle, poultry and sheep manure were applied in traditional method (superficial) or in trench and showed that application of organic manure in trench enhanced leaf $\mathrm{N}, \mathrm{K}, \mathrm{Ca}, \mathrm{mg}$ and $\mathrm{Zn}$ content as compared with the traditional method "superficial application".

As for the effect of bio-fertilizers application Mostafa (2002) inoculatedWashington navel orange trees with Nitrobien $(50 \mathrm{~g} /$ tree) or Rizobacterien $(100 \mathrm{~g} /$ tree). The results showed that Rhizobacterien inoculation in surpassed Nitrobien inoculation in improving leaf nitrogen, potassium, calcium, magnesium, iron, manganese and zinc content.

\section{Yield and its components}

Date in Tables $(8,9 \& 10)$ show effect of different organic manure sources with application method and bio-fertilizers ( $\mathrm{N}$ fixing bacteria) on yield and its components i.e. average number of clusters and average cluster weight of Flame Seedless grapevines during 2016 and 2017 seasons.

\section{a. Yield/vine}

Regarding different organic manure sources with application method treatments, data clarify that all organic manure sources with trench application had the highest significant values as compared to with superficial application. Highest significant yield/vine was obtained with poultry manure followed by compost, while city west compost came in the third position in both seasons of study.

With respect to bio-fertilizers application, data show that vines receiving of Rhizobacterien application produced significantly the highest values as compared to Nitrobien application, which it had significantly the least one in both seasons of study.

Concerning interaction between type of organic manure with application method and bio-fertilizers application, the highest significant values was attained by poultry manure with trench application + Rhizobacterien, whereas city west compost with superficial application + Nitrobien resulted in significantly the least one in both seasons of study.

\section{b. Number of clusters}

Regarding different organic manure sources with application method treatments, it is obvious that no significant difference among them in both seasons of study.

With respect to bio-fertilizers application, data show that no significant difference between Rhizobacterien and Nitrobien applications in both seasons of study.

Concerning interaction between type of organic manure with application method and bio-fertilizers application, it is obvious that no significant difference between them in both seasons of study.

\section{c. Cluster weight}

Regarding different organic manure sources with application method treatments, data clarify that all organic 
Effect of bio fertilizer, organic manure sources and application method on

manure sources with trench application had the highest significant values as compared to with superficial application. Highest significant cluster weight was obtained with poultry manure followed by compost, while city west compost came in the third position in both seasons of study.

Table (8): Effect of organic fertilizer with application method and bio-fertilizer application on yield/vine $(\mathrm{kg})$ of Flame Seedless grapevines during 2016 and 2017 seasons

\begin{tabular}{|c|c|c|c|c|c|c|}
\hline \multirow{2}{*}{ Organic fertilizer $\quad$ Bio-fertilizer } & \multicolumn{2}{|c|}{ Rhizobacterien } & \multicolumn{2}{|c|}{ Nitrobien } & \multicolumn{2}{|c|}{ Mean } \\
\hline & 1st & 2nd & 1st & 2nd & 1st & 2nd \\
\hline Poultry manure with trench application & 14.04 & 14.90 & 13.62 & 14.52 & 13.83 & 14.71 \\
\hline th superficial application & 13.43 & 14.18 & 13.35 & 14.14 & 13.39 & 14.16 \\
\hline Compost with trench application & 13.56 & 14.26 & 13.50 & 14.25 & 13.53 & 14.26 \\
\hline Compost with superficial application & 13.33 & 14.02 & 13.26 & 13.94 & 13.30 & 13.98 \\
\hline City wes & 13.22 & 13.94 & 13.11 & 13.77 & 13.17 & 13.86 \\
\hline $\begin{array}{l}\text { City west compost with sup } \\
\text { application }\end{array}$ & 13.04 & 13.74 & 13.01 & 13.68 & 13.03 & 13.71 \\
\hline Mean & 13.44 & 14.17 & 13.31 & 14.05 & & \\
\hline New L.S.D at $5 \%$ & \multicolumn{2}{|c|}{ Organic fertilizer } & \multicolumn{2}{|c|}{ Bio-fertilizer } & \multicolumn{2}{|c|}{ Interaction } \\
\hline First season & \multicolumn{2}{|c|}{0.16} & \multicolumn{2}{|l|}{0.11} & \multicolumn{2}{|l|}{0.22} \\
\hline Second season & \multicolumn{2}{|l|}{0.13} & \multicolumn{2}{|l|}{0.09} & 0.18 & \\
\hline
\end{tabular}

Table (9): Effect of organic fertilizer with application method and bio-fertilizer application on number of clusters of Flame Seedless grapevines during 2016 and 2017 seasons

\begin{tabular}{|c|c|c|c|c|c|c|}
\hline \multirow[b]{2}{*}{ Organic fertilizer } & \multicolumn{2}{|c|}{ Rhizobacterien } & \multicolumn{2}{|c|}{ Nitrobien } & \multicolumn{2}{|c|}{ Mean } \\
\hline & 1st & 2nd & 1st & 2nd & 1st & 2nd \\
\hline Poultry manure with trench application & 34.74 & 35.03 & 34.96 & 34.92 & 34.85 & 34.97 \\
\hline Poultry manure with superficial application & 34.96 & 34.93 & 34.92 & 34.94 & 34.94 & 34.94 \\
\hline Compost with trench application & 35.00 & 34.96 & 35.08 & 34.94 & 35.04 & 34.95 \\
\hline Compost with superficial application & 35.02 & 35.06 & 35.05 & 34.93 & 35.04 & 34.99 \\
\hline City west compost with trench application & 35.03 & 34.94 & 35.03 & 34.97 & 35.03 & 34.95 \\
\hline $\begin{array}{l}\text { City west compost with superficial } \\
\text { application }\end{array}$ & 34.96 & 35.03 & 35.16 & 34.96 & 35.06 & 34.99 \\
\hline Mean & 34.95 & 34.99 & 35.03 & 34.94 & & \\
\hline New L.S.D at $5 \%$ & Orgar & ertilizer & & $\begin{array}{l}\text { Bio- } \\
\text { fertilizer }\end{array}$ & & ction \\
\hline First season & N.S. & & & N.S. & N.S. & \\
\hline Second season & N.S. & & & v.S. & N.S. & \\
\hline
\end{tabular}


Table (10): Effect of organic fertilizer with application method and bio-fertilizer application on average cluster weight (g) of Flame Seedless grapevines during 2016 and 2017 seasons

\begin{tabular}{|c|c|c|c|c|c|c|}
\hline \multirow{2}{*}{ Organic fertilizer $\quad$ Bio-fertilizer } & \multicolumn{2}{|c|}{ Rhizobacterien } & \multicolumn{2}{|c|}{ Nitrobien } & \multicolumn{2}{|c|}{ Mean } \\
\hline & 1st & 2nd & 1st & 2nd & 1st & 2nd \\
\hline \multirow{2}{*}{$\begin{array}{l}\text { Poultry manure with trench application } \\
\begin{array}{l}\text { Poultry manure with superficial } \\
\text { application }\end{array}\end{array}$} & 404.13 & 425.41 & 389.60 & 415.80 & 396.87 & 420.61 \\
\hline & 384.11 & 405.90 & 382.33 & 404.71 & 383.22 & 405.31 \\
\hline Compost with trench application & 387.43 & 407.93 & 384.85 & 407.87 & 386.14 & 407.90 \\
\hline Compost with superficial application & 380.60 & 399.94 & 378.33 & 399.12 & 379.47 & 399.53 \\
\hline \multirow{2}{*}{$\begin{array}{l}\text { City west compost with trench } \\
\text { application } \\
\text { City west compost with superficial } \\
\text { application }\end{array}$} & 377.40 & 399.02 & 374.20 & 393.76 & 375.80 & 396.39 \\
\hline & 373.00 & 392.27 & 370.03 & 391.31 & 371.52 & 391.79 \\
\hline Mean & 384.45 & 405.08 & 379.89 & 402.10 & \multirow{2}{*}{\multicolumn{2}{|c|}{ Interaction }} \\
\hline New L.S.D at $5 \%$ & \multicolumn{3}{|c|}{ fertilizer } & & & \\
\hline \multirow{2}{*}{$\begin{array}{l}\text { First season } \\
\text { Second season }\end{array}$} & \multicolumn{2}{|c|}{4.13} & & & \multicolumn{2}{|c|}{5.86} \\
\hline & \multicolumn{2}{|c|}{4.05} & & .87 & \multicolumn{2}{|c|}{5.74} \\
\hline
\end{tabular}

With respect to bio-fertilizers application, data show that vines receiving of Rhizobacterien application produced significantly the highest values as compared to Nitrobien application, which it had significantly the least one in both seasons of study.

Concerning interaction between type of organic manure with application method and bio-fertilizers application, the highest significant values was attained by poultry manure with trench application + Rhizobacterien, whereas city west compost with superficial application + Nitrobien resulted in significantly the least one in both seasons of study.

These results are in harmony with those obtained by Seleem - Basma and Telep (2008 who worked on Superior grapevines found that application of the recommended rate of $\mathrm{N}$ as inorganic at 50 to $75 \%$ as well as organic plus bioforms at 25 to $50 \%$ resulted in an obvious promotion on the yield rather than application of $\mathrm{N}$ completely via inorganic forms. (Uwakiem, 2011) found that Yield of Banaty grapevines was remarkably enhanced when the vines received $N(100 \mathrm{~g} / \mathrm{vine})$ via $50 \%$ inorganic as well as $\mathbf{5 0} \%$ organic and biofertilizers rather than using $\mathbf{N}$ completely via mineral source only. Conradie (2001) cluster weight as well as yield of grapevine cvs Bulcettraube and Heroldrebe was greatly stimulated as a result of fertilizing the grapevines with poultry manure at $50 \mathrm{t} / \mathrm{ha}$ on trench method. As for the effect of bio-fertilizers application (Abd EI hady 2003) found thatapplication of bio fertilizers biogen Rhizobactrin and microbein resulted in a positive significant effect on berry weight of flame seedless grape vines aspecially bio gein at $40 \mathrm{G}$ as compared with the control.

\section{Physical characteristics of berries}

As shown in (Tables $11 \& 12$ ), it is obvious that physical characteristics of berries were significantly affected by organic manure with application method and bio-fertilizers application treatments during 2016 and 2017 seasons. 


\section{a. Weight of 100 berry}

Regarding different organic manure sources with application method treatments, data clarify that all organic manure sources with trench application had the highest significant values as compared to with superficial application. Highest significant weight of 100 berry was obtained with poultry manure followed by compost, while city west compost came in the third position in both seasons of study.

With respect to bio-fertilizers application, data show that vines receiving of Rhizobacterien application produced significantly the highest values as compared to Nitrobien application, which it had significantly the least one in both seasons of study.

Concerning interaction between type of organic manure with application method and bio-fertilizers application, the highest significant values was attained by poultry manure with trench application + Rhizobacterien, whereas city west compost with superficial application + Nitrobien resulted in significantly the least one in both seasons of study.

\section{b. Size of 100berry}

Regarding different organic manure sources with application method treatments, data clarify that all organic manure sources with trench application had the highest significant values as compared to with superficial application. Highest significant size of 100 berry was obtained with poultry manure followed by compost, while city west compost came in the third position in both seasons of study.

With respect to bio-fertilizers application, data show that vines receiving of Rhizobacterien application produced significantly the highest values as compared to Nitrobien application, which it had significantly the least one in both seasons of study.

Table (11): Effect of organic fertilizer with application method and bio-fertilizer application on average weight of 100berry (g) of Flame Seedless grapevines during 2016 and 2017 seasons

\begin{tabular}{|c|c|c|c|c|c|c|}
\hline \multirow{2}{*}{\begin{tabular}{|ll} 
Organic fertilizer & Bio-fertilizer \\
\end{tabular}} & \multicolumn{2}{|c|}{ Rhizobacterien } & \multicolumn{2}{|c|}{ Nitrobien } & \multicolumn{2}{|c|}{ Mean } \\
\hline & 1st & 2nd & 1st & 2nd & 1st & 2nd \\
\hline Poultry manure with trench application & 384.21 & 393.35 & 383.60 & 392.31 & 383.91 & 392.83 \\
\hline $\begin{array}{l}\text { Poultry manure with superficial } \\
\text { application }\end{array}$ & 345.37 & 355.12 & 343.23 & 353.51 & 344.30 & 354.32 \\
\hline Compost with trench application & 349.34 & 370.35 & 348.63 & 359.60 & 348.99 & 364.98 \\
\hline Compost with superficial application & 338.92 & 349.72 & 335.24 & 348.50 & 337.08 & 349.11 \\
\hline $\begin{array}{l}\text { City west compost with trench } \\
\text { application }\end{array}$ & 328.71 & 347.17 & 325.63 & 343.47 & 327.17 & 345.32 \\
\hline \begin{tabular}{|l}
$\begin{array}{l}\text { City west compost with superficial } \\
\text { application }\end{array}$ \\
\end{tabular} & 319.58 & 341.87 & 318.96 & 340.32 & 319.27 & 341.10 \\
\hline Mean & 344.36 & 359.60 & 342.55 & 356.29 & & \\
\hline New L.S.D at $5 \%$ & Orga & rtili & & $r$ & & n \\
\hline First season & 2.35 & & 1.67 & & 3.34 & \\
\hline Second season & 1.99 & & 1.41 & & 2.82 & \\
\hline
\end{tabular}


Table (12): Effect of organic fertilizer with application method and bio-fertilizer application on average size of 100berry (cm3) of Flame Seedless grapevines during 2016 and 2017 seasons

\begin{tabular}{|c|c|c|c|c|c|c|}
\hline \multirow{2}{*}{ Organic fertilizer $\quad$ Bio-fertilizer } & \multicolumn{2}{|c|}{ Rhizobacterien } & \multicolumn{2}{|c|}{ Nitrobien } & \multicolumn{2}{|c|}{ Mean } \\
\hline & 1st & 2nd & 1st & 2nd & 1st & 2nd \\
\hline Poultry manure with trench application & 372.88 & 385.93 & 335.48 & 348.95 & 354.18 & 367.44 \\
\hline $\begin{array}{lll}\text { Poultry manure } & \text { with } & \text { superficial } \\
\text { application }\end{array}$ & 313.72 & 330.37 & 313.10 & 328.83 & 313.41 & 329.60 \\
\hline Compost with trench application & 316.76 & 344.13 & 314.23 & 337.03 & 315.50 & 340.58 \\
\hline Compost with superficial application & 307.53 & 328.63 & 307.30 & 327.53 & 307.42 & 328.08 \\
\hline $\begin{array}{lcccc}\begin{array}{c}\text { City } \\
\text { application }\end{array} & \text { compost } & \text { with } & \text { trench } \\
\end{array}$ & 303.58 & 324.54 & 294.11 & 318.70 & 298.85 & 321.62 \\
\hline $\begin{array}{l}\text { City west compost with superficial } \\
\text { application }\end{array}$ & 292.80 & 304.47 & 275.48 & 298.03 & 284.14 & 301.25 \\
\hline Mean & 317.88 & 336.35 & 306.62 & 326.51 & & \\
\hline New L.S.D at $5 \%$ & Organic & fertilizer & Bio-fer & tilizer & Interac & tion \\
\hline First season & 2.45 & & 1.74 & & 3.48 & \\
\hline Second season & 2.16 & & 1.53 & & 3.06 & \\
\hline
\end{tabular}

Concerning interaction between type of organic manure with application method and bio-fertilizers application, the highest significant values was attained by poultry manure with trench application + Rhizobacterien, whereas city west compost with superficial application + Nitrobien resulted in significantly the least one in both seasons of study.

The obtained results are in agreement with those given by Abd EL-Ghafar (2002) studied effect of some organic $N$ fertilizers on quality of Red Roomy grapes. the best results with regard to quality of berries were obtained due to using filter mud at $30 \mathrm{~g} \mathrm{~N} / \mathrm{vine}(2.4 \mathrm{~kg})$ plus $120 \mathrm{~g} \mathrm{~N} /$ vine in mineral source.

As for the effect of bio-fertilizers application, Abd el hady (2003) showed that application of bio fertilizers biogen Rhizobactrin and microbein each at 10-40 $\mathrm{G} / \mathrm{vine}$ in combination with the mineral $\mathbf{N}$ fertilizer at 40-70 G/vine resulted in a positive significant effect on berry weight of flame seedless grape vines aspecially bio gein at $40 \mathrm{G}$ compared with the control.

\section{Chemical characteristics of berries}

Date in Tables $(13,14 \& 15)$ show effect of different organic manure sources with application method and biofertilizers ( $\mathrm{N}$-fixing bacteria) on chemical characteristics of berries i.e. TSS, acidity and TSS/acid ratio of Flame Seedless grapes during 2016 and 2017 seasons.

\section{a. TSS}

Regarding different organic manure sources with application method treatments, data clarify that all organic manure sources with trench application had the highest significant percentage as compared to with superficial application. Highest significant berry TSS juice was obtained with poultry manure followed by compost, while city west compost came in the third position in both seasons of study. 
Effect of bio fertilizer, organic manure sources and application method on

With respect to bio-fertilizers application, data show that vines receiving of Rhizobacterien application produced significantly the highest

percentage as compared to Nitrobien application, which it had significantly the least one in both seasons of study.

Table (13): Effect of organic fertilizer with application method and bio-fertilizer application on TSS (\%) of Flame Seedless grapevines during 2016 and 2017 seasons

\begin{tabular}{|l|c|c|l|l|l|l|}
\hline \multirow{2}{*}{ Brganic fertililizer } & Rhizobacterien & \multicolumn{2}{|c|}{ Nitrobien } & \multicolumn{3}{c|}{ Mean } \\
\cline { 2 - 8 } & 1 st & 2nd & 1 st & 2nd & 1st & 2nd \\
\hline Poultry manure with trench application & 16.83 & 16.89 & 16.78 & 16.77 & 16.81 & 16.83 \\
\hline Poultry manure with superficial application & 16.53 & 16.46 & 16.47 & 16.38 & 16.50 & 16.42 \\
\hline Compost with trench application & 16.72 & 16.64 & 16.59 & 16.57 & 16.66 & 16.61 \\
\hline Compost with superficial application & 16.34 & 16.31 & 16.29 & 16.27 & 16.32 & 16.29 \\
\hline City west compost with trench application & 16.21 & 16.19 & 16.13 & 16.07 & 16.17 & 16.13 \\
\hline City west compost with superficial application & 16.02 & 15.97 & 15.91 & 15.83 & 15.97 & 15.90 \\
\hline Mean & 16.44 & 16.41 & 16.36 & 16.32 & & \\
\hline
\end{tabular}

New L.S.D at $5 \%$

First season

Second season

Organic fertilizer Bio-fertilizer

0.10

0.06
0.07

0.04
Interaction

0.14

0.08

Table (14): Effect of organic fertilizer with application method and bio-fertilizer application on acidity (\%) of Flame Seedless grapevines during 2016 and 2017 seasons

\begin{tabular}{|c|c|c|c|c|c|c|}
\hline \multirow{2}{*}{ Organic fertilizer } & \multicolumn{2}{|c|}{ Rhizobacterien } & \multicolumn{2}{|c|}{ Nitrobien } & \multicolumn{2}{|c|}{ Mean } \\
\hline & 1st & 2nd & 1st & 2nd & 1st & 2nd \\
\hline Poultry manure with trench application & 0.54 & 0.51 & 0.57 & 0.53 & 0.56 & 0.52 \\
\hline Poultry manure with superficial application & 0.62 & 0.55 & 0.63 & 0.56 & 0.63 & 0.56 \\
\hline Compost with trench application & 0.59 & 0.54 & 0.61 & 0.54 & 0.60 & 0.54 \\
\hline Compost with superficial application & 0.65 & 0.57 & 0.65 & 0.57 & 0.65 & 0.57 \\
\hline City west compost with trench application & 0.66 & 0.58 & 0.67 & 0.59 & 0.67 & 0.59 \\
\hline City west compost with superficial application & 0.67 & 0.59 & 0.69 & 0.62 & 0.68 & 0.61 \\
\hline Mean & 0.62 & 0.56 & 0.64 & 0.57 & & \\
\hline New L.S.D at $5 \%$ & \multicolumn{2}{|c|}{ Organic fertilizer } & \multicolumn{2}{|c|}{ Bio-fertilizer } & \multicolumn{2}{|c|}{ Interaction } \\
\hline First season & \multicolumn{2}{|c|}{0.03} & \multicolumn{2}{|l|}{0.02} & \multicolumn{2}{|c|}{0.04} \\
\hline Second season & \multicolumn{2}{|c|}{0.01} & \multicolumn{2}{|l|}{0.01} & \multicolumn{2}{|c|}{0.02} \\
\hline
\end{tabular}


Table (15): Effect of organic fertilizer with application method and bio-fertilizer application on TSS/acid ratio of Flame Seedless grapevines during 2016 and 2017 seasons

\begin{tabular}{|c|c|c|c|c|c|c|}
\hline \multirow[b]{2}{*}{ Organic fertilizer } & \multicolumn{2}{|c|}{ Rhizobacterien } & \multicolumn{2}{|c|}{ Nitrobien } & \multicolumn{2}{|c|}{ Mean } \\
\hline & 1st & 2nd & $1 \mathrm{st}$ & 2nd & 1st & 2nd \\
\hline Poultry manure with trench application & 31.17 & 33.12 & 29.44 & 31.64 & 30.30 & 32.38 \\
\hline Poultry manure with superficial application & 26.66 & 29.93 & 26.14 & 29.25 & 26.40 & 29.59 \\
\hline Compost with trench application & 28.34 & 30.81 & 27.20 & 30.69 & 27.77 & 30.75 \\
\hline Compost with superficial application & 25.14 & 28.61 & 25.06 & 28.54 & 25.10 & 28.58 \\
\hline City west compost with trench application & 24.56 & 27.91 & 24.07 & 27.24 & 24.32 & 27.58 \\
\hline City west compost with superficial application & 23.91 & 27.07 & 23.06 & 25.53 & 23.48 & 26.30 \\
\hline Mean & 26.63 & 29.58 & 25.83 & 28.82 & & \\
\hline New L.S.D at $5 \%$ & \multicolumn{2}{|c|}{ Organic fertilizer } & \multicolumn{2}{|c|}{ Bio-fertilizer } & \multicolumn{2}{|c|}{ Interaction } \\
\hline First season & \multicolumn{2}{|l|}{1.02} & \multicolumn{2}{|l|}{0.72} & \multicolumn{2}{|l|}{1.44} \\
\hline Second season & \multicolumn{2}{|l|}{0.89} & \multicolumn{2}{|l|}{0.63} & \multicolumn{2}{|l|}{1.26} \\
\hline
\end{tabular}

Concerning interaction between type of organic manure with application method and bio-fertilizers application, the highest significant percentage was attained by poultry manure with trench application + Rhizobacterien, whereas city west compost with superficial application + Nitrobien resulted in significantly the least one in both seasons of study.

\section{b. Acidity}

Regarding different organic manure sources with application method treatments, data clarify that all organic manure sources with trench application had the least significant percentage as compared to with superficial application. Least significant berry acidity juice was obtained with poultry manure followed by compost, while city west compost came in the third position in both seasons of study.

With respect to bio-fertilizers application, data show that vines receiving of Rhizobacterien application produced significantly the least percentage as compared to Nitrobien application, which it had significantly the highest one in both seasons of study.

Concerning interaction between type of organic manure with application method and bio-fertilizers application, the least significant percentage was attained by poultry manure with trench application + Rhizobacterien, whereas city west compost with superficial application + Nitrobien resulted in significantly the highest one in both seasons of study.

\section{c. TSS/acid ratio}

Regarding different organic manure sources with application method treatments, data clarify that all organic manure sources with trench application had the highest significant values as compared to with superficial application. Highest significant berry TSS/acid ratio juice was obtained with poultry manure followed by compost, while city west compost came in the third position in both seasons of study. 
With respect to bio-fertilizers application, data show that vines receiving of Rhizobacterien application produced significantly the highest values as compared to Nitrobien application, which it had significantly the least one in both seasons of study.

Concerning interaction between type of organic manure with application method and bio-fertilizers application, the highest significant values was attained by poultry manure with trench application + Rhizobacterien, whereas city west compost with superficial application + Nitrobien resulted in significantly the least one in both seasons of study.

These results are in harmony with those obtained by ...Contoman (2005). who found that found that combined application of $\mathbf{N}$ in organic and inorganic forms resulted in the highest fruit sugars of Thompson seedless grapevine compared with using $\mathbf{N}$ via inorganic from onl andSeleem -Basma and Telep (2008) who worked on Superior grapevines found that application of the recommended rate of $\mathrm{N}$ as inorganic $\mathrm{N}$ at 50 to $75 \%$ as well as organic plus bioforms at 255 to $50 \%$ resulted in an obvious promotion on the quality of the berries rather than application of $\mathrm{N}$ completely via inorganic form .

As for the effect of bio-fertilizers application, Akl et al., 1997) found that found that the grapevines that inoculated with Rhizobacterien and nitrobein gave a hily improving in the chemical properties of berries and the differences between treated and untreated vines were significant and El-Mamlouk et al., (2016) Superior grapevines fertilized with compost, biofertilizers namely (Bacillus megatherium, Bacillus circulanse and Azotoacter Chroococcum), humic acid improved berries characteristics
From the foregoing results, it can be concluded that application of poultry manure with trench application + Rhizobacterien was the best management system for achieving the best vegetative growth parameters, leaf mineral content and ensuring the best yield with its components as well as fruit quality attributes of Flame Seedless grapevines.

\section{REFERENCES}

Abd EL-Ghafar, G. E. (2002). Effect of some organic nitrogen fertilizers on growth and productivity of red roomy grapevines (Vitis vinifera L.). M.Sc. Thesis, Fac. of. Agric., Minia Univ., Egypt.

Abd EL-Hady, A. M. (2003). Response of flame Seedless vines to application of some bio fertilizers. Minia J. Of Agric. Res. \& Develop. 23 (4): 667- 680.

Abdel -Reheem, A.; El- Wakeel, H.; Abd El- Hamid, A. And Mansour- Noha, A.E. (2015): Effect of organic and bioorganic of nitrogen fertilization on growth, yield, and fruit quality and nutritionl status of superior grapevines, J.Biol. Chem. Environ, Sci. 10 (1): 481-500.

Abd El-Wahab, M.A. (2011). Reducing the Amount of Mineral Nitrogen Fertilizers for Red Globe Grapevines by Using Different Sources of Organic Fertilizers. Journal of American Science 2011; 7(8):810-822] (ISSN: 1545-1003].

Ahmed, E. A. M. (2007). Response of some seedless grape cultivars to different cultural treatments under Assiut conditions. Ph. D. Thesis Fac. of Agric. Assiut Univ.m Egypt.

Ahmed, F. F. and M. H. Morsy (1999). A new method for measuring leaf area in different fruit species. Minia. J. Of Agric. Rec. \& Dev. 19:97- 105.

AKL, A. M., F.F. Ahmed, F. M. Morsy and M.A. Ragab (1997). The beneficial effect Of bio-fertilizers on red roomy 
grapevines ( vitis vinefera L ) b-the effect on berry set, yield and quality of berries. annals of agriculture science moshtohor ,35 (1)497-502.

Association of Official Agricultural Chemists (2000). Official Methods of analysis (A.O.A.C) , $12^{\text {th }}$ Ed .Benjamin Franklin Station , D.C.U.S.A. pp .490510.

Barman, M., S. Paul, A.G. Choudhury, P. Roy and J. Sen (2017). Biofertilizers as prospective input for sustainable agriculture in India. International Journal of Current Microbiology and Applied Sciences.

Chapman, H. D. and Pratt (1965). Methods of analysis for Soils, plants and water. Univ. of California. Division of Agric., Sci. 172- 173.

Contoman, M. (2005). Research concerning the influence of mineral and organic fertilization upon the intensity of physiological processes and productivity in vines. Lucrari Stiinitifice Universitatea de stiinte Agricole Si Medicina Veterinara "lonescu de la Brad" last, seria Agronomic, Romania 48: 3-8.

El-Mamlouk, E. A. H., M. M. Refaai and A. M. R. A. Abdelaziz (2016). Effect of humic acid, compost and biofertilization on fruiting of superior seedless grapevines : Arab Universities Journal of Agricultural Sciences 2016 Vol.24 No.1 pp.169-184 ref.31.

EL-Nagar, E.M. (1996). Effect of applying some organic residues to sand calcareous soils on growth and composition of some plants. M.Sc. Thesis, Fac. of Agric., Mansoura Univ.

Guo, B., J. Yang, R. Lu and S. Yu (2000). Effect of Komix on the growth and fruiting of Red Fuji apple variety. J. of Fruit Sci., 17 (1): 73-75.

Harhash, M.M. and Abd EL-Nasser (2000). Effect of organic manures in combination with elemental sulphur on soil physical and chemical characteristics, yield, fruit quality, leaf water contents and nutritional status of Flame seedless grapevines. J. Agric. Sci. Mansoura Univ., 25(5): 2819-2837.

Hussien, A.M., T.A. El-Maghraby, H.M. Sherif and S.A. El-Shal (2005). Effect of liquid organic fertilization techniques on yield and chemical composition of pear and apricot trees grown in sandy soils at South Tahrir province. Fayoum J. Agric. Res. \& Dev., 19 (2): 224238.

Kassem, H.A. and H.A. Marzouk (2002). Effect of organic and/or mineral nitrogen fertilization on the nutritional status, yield and fruit quality of Flame Seedless grapevines grown in calcareous soils. J. adv. Res. 7(3): 117 $-126$.

Moustafa, M.H. (2002). Studies on fertilization of Washington navel orange trees. Ph.D Dissertation Fac .of Agric ,Moshtohor,Zagazig University ,Benha Branch ,Egypt.

Nasser, L.N. (1998). Utilization of the municipal carbage (MG) as a soil amendment Alex. J. Agric. Res., 43(3): 31 7-332.

Omar, A H. (2005). Fertilization of Thompson seedless grapevines with mineral and organic source of nitrogen. J. Agric. Sci. Mansoura Univ. 30 (12): 7855-7862.

Pal, S., H.B. Singh, A. Farooqui and A. Rakshit (2015). Fungal biofertilizers in Indian agriculture: Perception, demand and promotion. Journal of Eco-friendly Agriculture

Salama, A. S. M. (2002). Response of some fruit species transplants and trees to organic fertilization Ph.D Dissertation, Fac. Agric., Moshtohorm Zagazig Univ. Benha Branch, Egypt.

Seleem- Basma, M. and A. M. Telep (2008). Effect of organic and biofertilizers as partial substitute for inorganic nitrogen in superior 
grapevines. Minia J. of agric. Res. \& Develop. Vol. 28 (1) 23-35.

Sharma, A., S. Kumar, N. Ahmed, O.C. Sharma and S. Debnath (2015). Protection of fruit growing soils from the threats on the mark. In: Sharma A et al., editors. So il Management Strategies-Thriving to Optimise Fruits Production. New Delhi: Kalyani Publishers. pp. 158-170.

Shelat, H.N., R.V. Vyas and Y.K. Jhala (2017). Biofertilizers and PGPR for evergreen agriculture. In: Verma DK, Srivastav PP, editors. Microorganisms in Sustainable Agriculture, Food and the Environment. Boca Raton: CRC Press.

Snedecor, G. W. and W. G. Cochran (1990). Statistical Methods. $7^{\text {th }}$ Ed. The lowa State Univ. Press. Ames, lowa, USA. P. 593.

Singh, M., M.L. Dotaniya, A. Mishra, C.K. Dotaniya, K.L. Regar and M. Lata (2016). Role of biofertilizers in conservation agriculture. In: Bisht JK et al., editors. Conservation Agriculture. Singapore: Springer; pp. 113-134

Trimurtulu, N. and DLN. Rao (2014). Liquid Microbial Inoculants and their Efficacy on Field Crops, ANGRAU, Agricultural Research Station, Amaravathi, pp 54.

Uwakiem, M. Kh. (2011). Effect of some organic, bio, and slow relaase $\mathrm{N}$ fertilizers as well as some antioxidants on vegetative growth, yield and berries quality of Thompson seedless grapevines. Ph. D, Thesis. Fac. of Agric. Minia Univ. Egypt.

Vessey, J. K. (2003). Plant growth promoting rhizobacteria as biofertilizer. Plant Soil 255:571-586

Wilde, S. A., R. B. Corey, J. G. Layer and G. K. Voigt (1985). soils and plant Analysis for Tree Culture. Mohan Primlani, Oxford \& IBH Publishing Co., New Delhi, India, P 1-142. 
تأثير التسميد الحيوى ومصادر وطريقة اضافة السماد العضوى على النمو الخضرى والمحتوى المعدنى للاوراق ومحصول وجودة ثمار عنب الفليم سيدلس

عبدالله السيد حسن ، محمد عبدالغفار محمد فؤاد سالم

قسم البساتين - كلية الزراعة - جامعة المنوفية

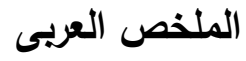

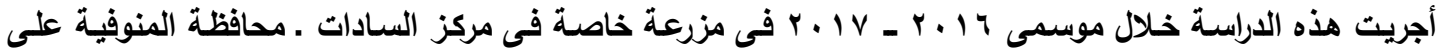
كرمات عنب فليم سيدلس عمر سبع سنوات منزرعة على ابعاد بx متر في تربة رملية وتحت نظام الرى بالتتقيط ـ وكان

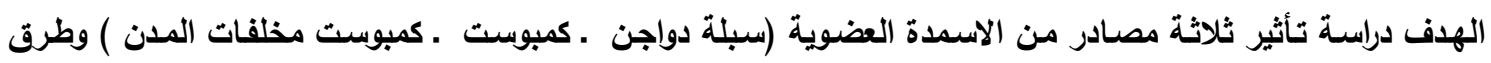

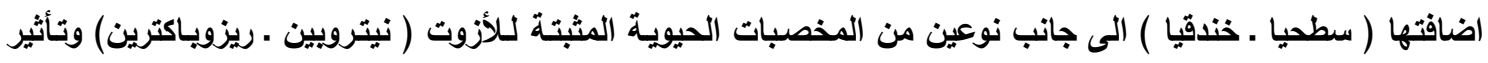
التفاعل بينهم على صفات النمو الخضرى و محتوى الاولق من الغناصر و المحصول و مكوناته وكذلك جودة الثمار . وقدات اشتملت التجربة على 12معاملة

اوضحت النتائج ان إضافة سماد سبلة الدواجن بطريقة الإضافة الخندقية + الريزوياكترين قد حققت افضل معايير الجودة لصفات النمو الخضرى ومحتوى الاورلق من عناصر النيتروجين والفوسفور والبوتاسيوم وكذلك المحصول وصفات الإفئه جودة الثمار لكرمات عنب القليم سيالس. 
